В. В. Ковальов, кандидат юридичних наук,

заступник директора,

Донецький науково-дослідний експертно-

криміналістичний центр МВС України,

м. Маріуполь, Донецька обл.

ORCID: https://orcid.org/0000-0001-7172-5832

\title{
СУЧАСНІ ЕЛЕКТРОННІ СЕРВІСИ ЯК ЗАСІБ КОМУНІКАЦІЇ ЕКСПЕРТНИХ УСТАНОВ ІЗ ЗАМОВНИКАМИ ЕКСПЕРТНИХ ПОСЛУГ
}

\begin{abstract}
Мета статті - формування нових і розвиток чинних теоретичних положень, а також практичних можливостей використання електронних сервісів як засобу комунікації експертних установ із замовниками, надання пропозицій і практичних рекомендацій. Методологія. Для дослідження організаційно-технічних засад, положень і принципів упровадження сучасних засобів комунікації як основний використано діалектичний метод, що дозволило розглянути предмет статті в сукупності та взаємозв'язку його складників. Крім того, поставлені для досягнення мети завдання вирішувалися за допомогою комплексу загальнонаукових і спеціальних методів, у тому числі формально-логічних (аналіз, синтез, дедукція, індукція, аналогія, абстрагування), системно-структурного та порівняльно-правового. Результати дослідження грунтуються на узагальненні відомостей про сучасні тенденції розвитку комунікації в державних установах, зокрема в підрозділах Експертної служби МВС. Наукова новизна. Обгрунтовано необхідність створення системи взаємодії експертних установ із замовниками експертних послуг на платформі чат-ботів, запропоновано послідовність такої взаємодії. Висновки. Необхідність оптимізації комунікації суб'єктів судово-експертної діяльності аргументовано організаційно-правовими особливостями виконання судових експертиз. Узагальнено досвід використання державними установами й громадськими організаціями чат-ботів, що засвідчує зручність сервісів, які відповідають найкращим практикам. Окреслено переваги зазначеного засобу комунікації, що робить його повноцінним нематеріальним активом, а також ризики, викликані тим, що чат-боти, потребуючи правильного використання, не вирішують складних питань. Розроблено систему взаємодії експертних установ із замовниками послуг і запропоновано послідовність такої взаємодії. У меню сервісу (бота) передбачено опції «Мої документи», «Мої повідомлення». Надано пропозиції і рекомендації щодо використання в експертних установах чат-ботів як засобу комунікації.
\end{abstract}

Ключові слова: державна установа; судова експертиза; судово-експертна діяльність; замовник експертних послуг; цифровізація; діджиталізація; електронні сервіси; чат-бот.

\section{Вступ}

Сьогодні, коли цифрові технології активно впроваджуються в усі сфери життя суспільства, охоплюючи дедалі нові процеси його життєдіяльності, зазнають змін галузі економіки, духовний світ, ідеологія, змінюється звичний спосіб комунікації, отримання нової інформації тощо. Суспільство стає цифровим споживачем: використовує електронну пошту, соціальні мережі, месенджери. «Отже, «цифрова» галузь, включаючи електронні комунікації, інформаційне суспільство та аудіовізуальний ринок, зазнає найшвидших та найсуттєвіших змін в умовах сьогодення, тому помилки, недопрацювання, суперечності, законодавчі казуси у цій сфері неприпустимі, а необхідність законодавчих змін $\epsilon$ нагальною» (Dukhovna, 2019).

У 2018 р. Кабінет Міністрів України схвалив Концепцію розвитку цифрової економіки та суспільства України на 2018-2020 роки і затвердив план заходів щодо іiі реалізації. Основною метою документа є реалізація ініціатив, що перебувають у фокусі цифрового порядку денного України 2020 (цифрової стратегіi), для усунення бар'єрів на шляху цифрової трансформації України (Pro skhvalennia Kontseptsii, 2018) та, наголошує загал вчених (Tsyfrova adzhenda, 2016; Tsyfrova stratehiia, 2017), успішної інтеграції країни у глобальний ринок.

Розвиваючи напрям країни до діджиталізації, Кабінет Міністрів 2019 р. затвердив Положення про Міністерство цифрової трансформації України (Polozhennia pro Ministerstvo, 2019), в якому зазначено, що серед завдань цього центрального органу виконавчої влади - формування та реалізація державної політики в галузі цифровізації.

У спеціальній літературі, і це тенденція останніх років, частіше послуговуються поняттям «інформаційне забезпечення» (оперативно-розшукової роботи, експертної діяльності тощо), яке дедалі більш упевнено входить у практику розслідування правопорушень (Klimenko, 2018, s. 107). «Відповідно у 
руслі діджиталізації лежить і впровадження IT-технологій у судово-експертну діяльність, роль якої у встановленні істини, що реалізується відповідно до норм матеріального та процесуального права, $€$ беззаперечною» (Ruvin (Zah. red.), 2019, s. 6). Проте сьогодні головний термін, використовуваний для позначення трансформації галузей, - цифровізація (Koulu, Kallio, \& Hakkarainen, 2017, s. 1).

Питання використання інформаційних технологій і систем під час проведення судової експертизи вивчали Р. С. Бєлкін, П. Д. Біленчук, Л. Г. Еджубов, Н. І. Клименко, Є. Д. Лук'янчиков, Ю. О. Пілюков, М. С. Полевий, О. Р. Россинська, М. В. Салтевський, В. Г. Хахановський, О. Р. Шляхов та ін.

Так, Є. Д. Лук'янчиков зазначає, що інформаційне забезпечення доцільно розглядати у двох функціональних значеннях: як правове регулювання, визначаючи його сутність через інформаційний підхід із позиції повноти, досконалості, чіткості регулювання діяльності та як удосконалення діяльності - наукове, методичне забезпечення, використання знань криміналістики та інших прикладних і спеціальних дисциплін із метою підвищення якості діяльності (Lukianchykov, 2005, s.15).

Працюючи у зазначеному напрямі, дослідники висвітлювали проблеми, що стосуються різних галузей діяльності, як-от: електронні банки соціологічних даних (Horbachyk, 2009); еволюція цифрового уряду (Janowski, 2015); ініціативи урядового міжорганізаційного обміну інформацією (Gil-Garcia, \& Sayogo, 2016); послуги електронного врядування (Venkatesh, Thong, Chan, \& Hu, 2016); споживачі на ринку експертних послуг (Schneider, Meub, \& Bizer, 2016); упровадження нових технологій для підвищення ефективності надання послуг (Lupo, \& Velicogna, 2018); відкриті ресурси (Shevchenko, 2019); моделі комунікації в системі державного управління (Prysiazhniuk, 2019); ефективні соціальні комунікації (Shchokina, Tsariuk, \& Denisova, 2019); моделі розвитку електронного уряду (Iannacci, Seepma, de Blok, \& Resca, 2019); цифрова трансформація (Vial, 2019); електронні ресурси та сервіси як інструменти підвищення ефективності державної політики в різних сферах (Durman, \& Tokhtarova, 2020); співвідношення понять «державний» та «публічний» (Durman, 2020).

Проте, незважаючи на грунтовний науковий доробок, питання використання інформаційних технологій, упровадження сучасних інформаційних засобів у судово-експертну діяльність, що наразі є одним із пріоритетних напрямів розвитку державних, у тому числі експертних, установ, потребує додаткового теоретико-практичного вивчення. Зокрема, на часі поглиблене дослідження забезпечення ефективної комунікації із замовниками (ініціаторами) судових експертиз, працівни- ками правоохоронних та інших державних органів, громадянами.

\section{Мета й завдання дослідження}

Мета статті - формування нових та розвиток чинних теоретичних положень, а також практичних можливостей використання електронних сервісів як засобу комунікації експертних установ із замовниками, надання пропозицій і практичних рекомендацій.

Для досягнення зазначеної мети слід виконати такі завдання:

аргументувати необхідність оптимізації комунікації суб'єктів судово-експертної діяльності;

узагальнити досвід використання державними установами і громадськими організаціями чат-ботів;

окреслити переваги та ризики цього засобу комунікації;

розробити систему взаємодії експертних установ із замовниками послуг, запропонувати послідовність такої взаємодії;

надати пропозиції і рекомендації щодо використання в експертних установах як засобу комунікації чат-ботів.

\section{Виклад основного матеріалу}

Виконання судових експертиз сьогодні $€$ послугою, яку надають державні установи, зокрема й Експертна служба МВС України, фахівці якої проводять судові експертизи за постановами, винесеними слідчими Національної поліції та інших правоохоронних органів (Служби безпеки України, Державного бюро розслідувань тощо) або за ухвалами судів.

Своєчасне виконання судових експертиз, і це загальновизнано, являє собою чинник, що серед інших впливає на оперативність розслідування правопорушень (Pro zatverdzhennia Instruktsii, 2017). Водночас практику спілкування із замовниками експертних послуг щодо виконання експертиз сьогодні не можна назвати цілком ефективною.

До прикладу, надіслання результатів експертних проваджень (повідомлення про неможливість проведення судової експертизи, висновку судового експерта, що складають у письмовому вигляді) засобами електронного зв'язку не допускається (Pro zatverdzhennia Instruktsii, 2017), при цьому послуговуються поштовим сервісом, втрачаючи, звичайно, час. Зокрема, про необхідність надати додаткові матеріали (Pro sudovu ekspertyzu, 1994, st. 13) замовник дізнається лише після того, як отримав поштою заявлене експертом відповідне клопотання. Проте в разі порушення передбачених для цього строків експерт повертає матеріали без виконання (Pro zatverdzhennia Instruktsii, 2017, p. 7). 
Проблема раціонального використання часу постає й тоді, коли в процесі взаємодії із судовими органами листування може тривати тижнями, а то й місяцями.

Проблема оптимізації комунікації суб’єктів судово-експертної діяльності набуває особливого значення, якщо особі повідомлено підозру у вчиненні кримінального правопорушення, коли визначені жорсткі обмеження строків досудового розслідування (Kryminalnyi protsesualnyi kodeks, 2012).

Україна, за прикладом інших країн (Seеpma, de Blok, \& Van Donk, 2020), робить активні кроки, щоб підвищити якість державних послуг, використовуючи інформаційні та комунікаційні технології у ланцюжках їх постачання, а також вживає певних заходів, що сприяють інформаційно-комунікативному розвитку. Не стоять осторонь і експертні установи країни.

Сьогодні в Експертній службі МВС упроваджено систему електронного документообігу, яка дозволяє відстежувати перебіг виконання окремих документів, прискорювати інформування про зміну статусу виконання судових експертиз або про необхідність отримати їх результати чи інші документи (наприклад клопотання).

Але, убачається, постала потреба в налагодженні ефективної комунікації і між такими суб'єктами судово-експертної діяльності, як експертні установи та замовники судових експертиз. Розроблення і впровадження у діяльність електронного сервісу з використанням можливостей чат-ботів (працюють на основі Telegram або аналогічних систем обміну миттєвими повідомленнями - месенджерів) значно підвищить рівень такої взаємодії.

Месенджери, що давно із засобів для спілкування перетворилися на засоби для швидкого отримання інформації, $\epsilon$ потужним інструментом комунікації. I ключова роль у цьому належить ботам. За кордоном такими комп'ютерними програмами активно послуговуються уже не один рік. В Україні вони також набувають популярності, і не лише серед власників бізнесу, а й у державних органах.

Діапазон можливостей різних сучасних ботів загалом дуже широкий - від отримання розсилок до замовлення послуг. Так, розроблені на основі нейромереж i технологій машинного навчання чат-боти забезпечують ведення розмови за допомогою слухових або текстових методів. Це доволі універсальні засоби; їх застосовують, наприклад, для надання потрібної інформації, консультацій, розпізнавання емоцій або для розваг. Також «чат-боти або віртуальні співрозмовники використовуються в діалогових системах для різних практичних цілей, включаючи обслуговування клієнтів» (Skorokhod, 2017).
Натепер державними установами й громадськими організаціями розроблено та запроваджено кілька чат-ботів, серед них:

чат-бот у месенджері Telegram - для пошуку актуальних вакансій на порталі carrer.gov.ua (NADS zapuskaie chat-bot, 2020);

сервіс-чат-бот «Держслужбовець Тарас» - допомагає суб'єктам декларування у заповненні декларацій осіб, уповноважених на виконання функцій держави або місцевого самоврядування (V Ukraini pratsiuie, 2018);

чат-бот Державної міграційної служби України - за його допомогою можна отримати консультацію про оформлення біометричних документів і скористатися електронними сервісами служби (Chat-bot: DMS, 2019);

чат-бот «Опендатабот» - працює в популярних мессенджерах Telegram, Facebook Messenger, Skype, Viber і забезпечує доступ до публічної інформації у формі відкритих даних (Pro dostup do publichnoi informatsii, 2011, st. $\left.10^{1}\right)$, надаючи в такий спосіб громадянам і бізнесу можливість спостерігати за їх змінами (Opendatabot, 2020).

Перевагами цього засобу комунікації, на нашу думку, є:

відсутність необхідності встановлювати та налаштовувати додаткове програмне забезпечення (більшість користувачів використовують месенджери постійно);

багатоплатформність (інтерфейс і досвід користувача зазвичай однакові в будь-яких операційних системах і пристроях);

відносно невелика вартість розроблення та підтримання електронного сервісу;

порівняно низькі вимоги до апаратного забезпечення (сервера);

можливість інтеграції з будь-якими системами електронного документообігу чи іншими постачальниками даних (автоматизовані системи, системи управління контентом, системи управління процесами, будь-які бази даних, а то й звичайні файли з даними);

простий і доступний інтерфейс користувача;

відсутність тарифікації за кількість надісланих повідомлень;

можливість завантажувати (відправляти) файли і зображення.

Отже, систему взаємодії експертних установ із замовниками експертних послуг доцільно, зважаючи на окреслені переваги чат-ботів, створювати саме на цій платформі. Послідовність взаємодії може бути такою: під час реєстрації вхідного документа (постанови про призначення судової експертизи, заяви на проведення дослідження, експериментального відстрілу, технічного огляду зброї тощо) у системі електронного документо- 
обігу вносять контакти особи, яка отримуватиме повідомлення та переглядатиме поточний статус виконання цього документа (замовник), - номер мобільного телефону (кілька номерів). Замовник дослідження, спілкуючись із ботом, переходить за посиланням, яке розміщується на офіційному сайті експертної установи, або використовує QR-код, присвоєний йому системою електронного документообігу під час реєстрації вхідного документа.

Для меню сервісу (бота) пропонуються такі опції:

«Мої документи» (перелік усіх документів, які замовник надіслав до цієї установи);

«Мої повідомлення» (перелік усіх повідомлень, які система надіслала замовнику: про завершення судової експертизи та виконання постанови, про необхідність отримання результатів дослідження, про надіслання на його адресу клопотання тощо).

Після отримання запиту від замовника або в разі зміни статусу перебігу виконання документа (замовлення) формується повідомлення (рис. 1), що надсилається замовнику.

Ваші документи:
Постанова про призначення судової трасологічної
експертизи
Вхідний документ зареєстровано: 25.03 .2020
Поточний стан: Виконано
Отримати матеріали може або ініціатор, або інша особа за
наявності довіреності
Постанова про призначення судової дактилоскопічної
експертизи
Вхідний документ зареєстровано: 07.04.2020
Поточний стан: На виконаннІ
Write а теssаgе...

Рис. 1. Зразки повідомлень про стан виконання документів

У разі зміни статусу перебігу виконання документа замовнику проведення судової експертизи автоматично про це надсилається інформаційне повідомлення або інша інформація (рис. 2).

Доступ до інформації надаватиметься лише в разі звернення з того телефонного номера, який зазначено під час реєстрації вхідного документа. Дані зберігатимуться обмежений проміжок часу, якого достатньо для інформування замовника (ініціатора). Після отримання замовником (ініціатором) результатів виконання документа дані знищуватимуться.

Повідомлення системи не міститимуть ні персональних, ні конфіденційних (номер справи, ві-

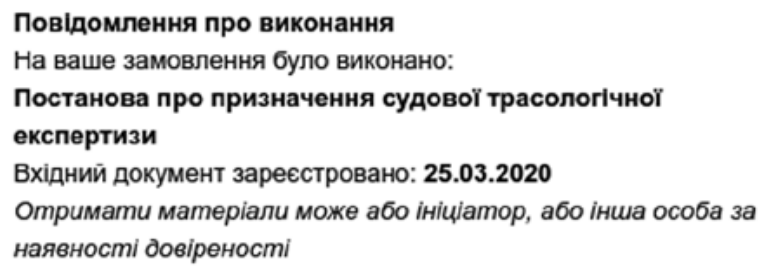

Рис. 2. Зразки повідомлень про зміну статусу перебігу виконання документа

домості про судового експерта, результати дослідження) даних (Pro informatsiiu, 1992).

Запропонований сервіс можна доповнювати додатковими можливостями, які підвищуватимуть ефективність взаємодії з усіма категоріями замовників експертних послуг (фізичними та юридичними особами), щодо, зокрема:

інформування про графік та умови надання послуг з експериментального відстрілу зброї, що у власності громадян та юридичних осіб (за аналогією з інформуванням замовників (ініціаторів) судових експертиз можна організувати інформування про отримання відповідних довідок);

інформування про можливість проведення окремих видів досліджень, їх вартість, місце замовлення послуги тощо;

можливості подання звернення чи зворотного зв'язку стосовно діяльності працівників експертної установи (відгуки, пропозиції, скарги), які керівництво оперативно розглядатиме з метою усунення недоліків і підвищення якості обслуговування замовників експертних послуг.

\section{Наукова новизна}

Обгрунтовано необхідність створення системи взаємодії експертних установ із замовниками експертних послуг на платформі чат-ботів, запропоновано послідовність такої взаємодії.

\section{Висновки}

1. Необхідність оптимізації комунікації суб’єктів судово-експертної діяльності аргумен- 
товано організаційно-правовими особливостями виконання судових експертиз, що полягають у необхідності забезпечення оперативного інформування замовників про перебіг виконання судової експертизи (повернення без виконання, клопотання судового експерта, завершення проведення судової експертизи).

2. Узагальнено досвід використання державними установами й громадськими організаціями чат-ботів, що засвідчує зручність сервісів, які відповідають найкращим практикам.

3. Окреслено переваги зазначеного засобу комунікації, що робить його повноцінним нематеріальним активом. При цьому ризики полягають у тому, що чат-боти потребують правильного використання (див. рис. 1 і 2) і не вирішують складних питань.

4. Розроблено систему взаємодії експертних установ із замовниками послуг і запропоновано послідовність такої взаємодії. У меню сервісу (бота) передбачено опції «Мої документи», «Мої повідомлення».

5. Надано пропозиції і рекомендації щодо використання в експертних установах чат-ботів як засобу комунікації, зокрема: зміст сервісів, які необхідно реалізувати, та послідовність взаємодії замовника 3 чат-ботом із метою отримання чи надання необхідної інформації.

\section{References}

Chat-bot: DMS zaprovadzhuie novyi elektronnyi servis. (2019). Uziato z https://dmsu.gov.ua/news/dms/4202.html [in Ukrainian].

Dukhovna, O. (2019, Lystop. 5). Ukraina «v tsyfri»: napriamky reformuvannia. Yurydychna hazeta, 45-46, 699-700. Uziato $\mathrm{z}$ https://yur-gazeta.com/publications/practice/informaciyne-pravo-telekomunikaciyi/ukrayina-v-cifri-napryamki-reformuvannya.html [in Ukrainian].

Durman, M. O. (2020). Spivvidnoshennia poniat «derzhavnyi» ta «publichnyi» u sferi rehuliatornoi polityky: aktualizatsiia poniatiino-terminolohichnoho aparatu. Naukovyi visnyk: derzhavne upravlinnia, 2 (4), 135-149 [in Ukrainian]. DOI: https://doi.org/10.32689/2618-0065-2020-2(4)-135-148 22.

Durman, M. O., \& Tokhtarova, I. M. (2020). Elektronni resursy ta servisy yak instrumenty pidvyshchennia efektyvnosti derzhavnoi rehuliatornoi polityky. Teoriia ta praktyka derzhavnoho upravlinnia i mistsevoho samovriaduvannia, 1 [in Ukrainian]. DOI: https://doi.org/10.35546/kntu2308-8834/2020.1.13.

Gil-Garcia, J. R., \& Sayogo, D. S. (2016). Government interorganizational information sharing initiatives: understanding the main determinants of success. Government Information Quarterly, 33 (3), 572-582. DOI: https://doi.org/10.1016/j.giq.2016.01.006.

Horbachyk, A. P. (2009). Elektronni banky sotsiolohichnykh danykh. Ukrainskyi sotsium, 2 (29), 14-21 [in Ukrainian]. DOI: https://doi.org/10.15407/socium2009.02.014.

Iannacci, F., Seepma, A. P., de Blok, C., \& Resca, A. (2019). Reappraising maturity models in e-Government research: The trajectory-turning point theory. The Journal of Strategic Information Systems, 28 (3), 310-329.

DOI: https://doi.org/10.1016/j.jsis.2019.02.001.

Janowski, T. (2015). Digital government evolution: From transformation to contextualization. Government Information Quarterly, 32 (3), 221-236. DOI: https://doi.org/10.1016/j.giq.2015.07.001.

Klymenko, N. I. (2018). Zahalna teoriia sudovoi ekspertolohii: monohrafiia. Ternopil: Krok. $262 \mathrm{~s}$.

Koulu, R., Kallio, L., \& Hakkarainen, J. M. (2017). Law and Digitalization - an agenda for the future: research reports No 1, May 2017. Helsinki: University of Helsinki Legal Tech Lab. $17 \mathrm{~s}$.

DOI: https: //doi.org/10.31885/2019.00007.

Kryminalnyi protsesualnyi kodeks Ukrain: Zakon Ukrainy № 4651-VI. (2012). Uziato z https://zakon.rada.gov.ua/laws/ show/4651-17\#n1191 [in Ukrainian].

Lukianchykov, Ye. D. (2005). Informatsiine zabezpechennia rozsliduvannia zlochyniv (pravovi i taktyko-kryminalistychni aspekty). (Avtoref. dys. d-ra yuryd. nauk). Natsionalna akademiia vnutrishnikh sprav Ukrainy, Kyiv. 36 c. Uziato z http://194.44.11.130/cgi-bin/irbis_nbuv/cgiirbis_64.exe?C21COM=2\&I21DBN=ARD\&P21DBN=ARD\&IMAGE_ FILE_DOWNLOAD=1\&Z21ID=\&Image_file_name=DOC/2005/05ledtka.zip [in Ukrainian].

Lupo, G., \& Velicogna, M. (2018). Making EU Justice Smart? Looking into the Implementation of New Technologies to Improve the Efficiency of Cross Border Justice Services Delivery. In Rodríguez Bolívar, M. P. (Ed.), Smart Technologies for Smart Governments. Springer, New York, NY, pp. 95-121.

NADS zapuskaie chat-bot dlia poshuku derzhavnykh vakansii. (2020). Uziato z https://www.kmu.gov.ua/news/nads-zapustilo-chat-bot-dlya-poshuku-derzhavnih-vakansij [in Ukrainian].

Opendatabot: ofits. sait. (2020). Uziato z opendatabot.ua [in Ukrainian].

Polozhennia pro Ministerstvo tsyfrovoi transformatsii Ukrainy: zatv. postanovoiu Kabinetu Ministriv Ukrainy № 856. (2019). Uziato z https://zakon.rada.gov.ua/laws/show/856-2019-\%D0\%BF\#n12 [in Ukrainian].

Pro dostup do publichnoi informatsii: Zakon Ukrainy № 2939-VI. (2011). Uziato z https://zakon.rada.gov.ua/laws/ show/2939-17\#Text. 
Pro informatsiiu: Zakon Ukrainy № 2657-XII. (1992). Uziato z https://zakon.rada.gov.ua/laws/show/2657-12.

Pro skhvalennia Kontseptsii rozvytku tsyfrovoi ekonomiky ta suspilstva Ukrainy na 2018-2020 roky ta zatverdzhennia planu zakhodiv shchodo yii realizatsii: rozporiadzhennia Kabinetu Ministriv Ukrainy № 67-r. (2018). Uziato z https:// zakon.rada.gov.ua/laws/show/67-2018-r [in Ukrainian].

Pro sudovu ekspertyzu: Zakon Ukrainy № 4038-XII. (1994). Uziato z https://zakon.rada.gov.ua/laws/show/4038-12.

Pro zatverdzhennia Instruktsii z orhanizatsii provedennia ta oformlennia ekspertnykh provadzhen u pidrozdilakh Ekspertnoi sluzhby Ministerstva vnutrishnikh sprav Ukrainy: nakaz MVS Ukrainy № 591. (2017). Uziato z https://zakon.rada. gov.ua/laws/show/z1024-17.

Prysiazhniuk, P. V. (2019). Demokratychna model komunikatsii v systemi derzhavnoho upravlinnia Ukrainy: sutnist ta osnovni elementy. Teoriia ta praktyka derzhavnoho upravlinnia, 3 (66), 95-101 [in Ukrainian].

DOI: https://doi.org/10.34213/tp.19.03.11.

Ruvin, O. H. (Zah. red.). (2019). Sudovi ekspertyzy v protsesualnomu pravi Ukrainy: navch. posib. Kyiv: Lira-K. 424 s. [in Ukrainian].

Schneider, T., Meub, L., \& Bizer, K. (2016). Consumer Information in a Market for Expert Services: Experimental Evidence. SSRN Electronic Journal.

DOI: $10.2139 /$ ssrn.2802129.

Seepma, A. P., de Blok, C., \& Van Donk, D. P. (2020). Designing digital public service supply chains: four country-based cases in criminal justice. Supply Chain Management. DOI: https://doi.org/10.1108/SCM-03-2019-0111.

Shchokina, Ye. Yu., Tsariuk, Yu. S., \& Denisova, Ye. V. (2019). Efektyvni suspilni komunikatsii. Pryazovskyi ekonomichnyi visnyk, 6 (17), 251-256 [in Ukrainian].

DOI: https://doi.org/10.32840/2522-4263/2019-6-46.

Shevchenko, V. E. (2019). Servisy vidkrytykh danykh v Ukraini. Aktualni pytannia masovoi komunikatsii, 26, 41-53 [in Ukrainian]. DOI: https://doi.org/10.17721/2312-5160.2019.26.41-53.

Skorokhod, V. (2017). Vyznachennia zasobiv rozrobky chat-bota "pomichnyk abituriienta» dlia suchasnykh mesendzheriv. Uziato z https://phm.cuspu.edu.ua/nauka/konferentsii/fizyka-tekhnolohii-navchannia/99-2017/komp-iuterni-naukyta-informatsiini-tekhnolohii/1118-vyznachennya-zasobiv-rozrobky-chat-bota-pomichnyk-abituriyenta-dlya-suchasnykh-mesendzheriv.html [in Ukrainian].

Tsyfrova adzhenda Ukrainy - 2020: proiekt. (2016). 90 s. Uziato z https://ucci.org.ua/uploads/files/58e78ee3c3922. pdf?_cf_chl_jschl_tk__=325e284c5904a6785a25b589b8f01a4eea07fa05-1607426093-0-AfzFlAXphtT7Q6Hft_1-60y4cpWz_CRCpDFxwNvIOOtt_nAQ_gLh6Tqif8WylkOucUKYag-tW7DoKdyOHRn0WW7H0jYoIiCmAzPZiylcJFtHcTaFPSPISIB8nCZbR2PIdDhV01wSyqyXfnkjwNGODO6G3TsOmvEg7tXYr1_NzyAy29JfX_KrjsWxSXanRGMNZKyvMaCG4mLf5YUIH6zMW30nAFz7Lk21M0ZoUR7rHHYsh3ofZjUqu_RyBTKH4JMi2TvpbcXPBQ9ThovgLN4LlvI51ZI77w4bC-F6y50JzGrMQ1CAKGn_32YjmAos52M9R2MvifUQuo-4eFP8GHjr0uWTd255FGxWzlDltxnNsqgo [in Ukrainian].

Tsyfrova stratehiia Ukrainy 2020: uspishna intehratsiia Ukrainy u hlobalnyi rynok (2017, Berez. 6). Uziato z https://ckp.in.ua/ events/16407 [in Ukrainian].

Venkatesh, V., Thong, J. Y. L., Chan, F. K., \& Hu, P. J. H. (2016). Managing Citizens' Uncertainty in E-Government Services: The Mediating and Moderating Roles of Transparency and Trust. Information Systems Research, 27 (1), 87-111. DOI: https://doi.org/10.1287/isre.2015.0612.

Vial, G. (2019). Understanding digital transformation: A review and a research agenda. The Journal of Strategic Information Systems, 28 (2), 118-144.

DOI: https://doi.org/10.1016/j.jsis.2019.01.003.

V Ukraini pratsiuie elektronnyi servis-chat-bot «Derzhsluzhbovets Taras». (2018). Uziato z https://khoda.gov.ua/vukra\%D1\%97n\%D1\%96-pracju\%D1\%94- [in Ukrainian].

\section{Список використаних джерел}

Чат-бот: ДМС запроваджує новий електронний сервіс. (2019). Узято з https://dmsu.gov.ua/news/dms/4202.html.

Духовна, О. (2019, Листоп. 5). Україна «в цифрі»: напрямки реформування. Юридична газета, 45-46, 699-700. Узято 3 https:/yur-gazeta.com/publications/practice/informaciyne-pravo-telekomunikaciyi/ukrayina-v-cifri-napryamkireformuvannya.html.

Дурман, М. О. (2020). Співвідношення понять «державний» та «публічний» у сфері регуляторної політики: актуалізація понятійно-термінологічного апарату. Науковий вісник: державне управління, 2 (4), 135-149. DOI: https://doi.org/10.32689/2618-0065-2020-2(4)-135-148 22.

Дурман, М. О., \& Тохтарова, І. М. (2020). Електронні ресурси та сервіси як інструменти підвищення ефективності державної регуляторної політики. Теорія та практика державного управління і місиевого самоврядування, 1 DOI: https://doi.org/10.35546/kntu2308-8834/2020.1.13.

Gil-Garcia, J. R., \& Sayogo, D. S. (2016). Government interorganizational information sharing initiatives: understanding the main determinants of success. Government Information Quarterly, 33 (3), 572-582.

DOI: https://doi.org/10.1016/j.giq.2016.01.006. 
Горбачик, А. П. (2009). Електронні банки соціологічних даних. Украйнський соиіум, 2 (29), 14-21. DOI: https://doi.org/10.15407/socium2009.02.014.

Iannacci, F., Seepma, A. P., de Blok, C., \& Resca, A. (2019). Reappraising maturity models in e-Government research: The trajectory-turning point theory. The Journal of Strategic Information Systems, 28 (3), 310-329.

DOI: https://doi.org/10.1016/j.jsis.2019.02.001.

Janowski, T. (2015). Digital government evolution: From transformation to contextualization. Government Information Quarterly, 32 (3), 221-236.

DOI: https://doi.org/10.1016/j.giq.2015.07.001.

Клименко, Н. І. (2018). Загальна теорія судової експертології: монографія. Тернопіль: Крок. 262 с.

Koulu, R., Kallio, L., \& Hakkarainen, J. M. (2017). Law and Digitalization - an agenda for the future: research reports № 1, May 2017. Helsinki: University of Helsinki Legal Tech Lab. 17 s.

DOI: https: //doi.org/10.31885/2019.00007.

Кримінальний процесуальний кодекс України: Закон України № 4651-VI. (2012). Узято з https://zakon.rada.gov.ua/ laws/show/4651-17\#n1191.

Лук'янчиков, Є. Д. (2005). Інформаційне забезпечення розслідування злочинів (правові і тактико-криміналістичні аспекти). (Автореф. дис. д-ра юрид. наук). Національна академія внутрішніх справ України, Київ. 36 с. Узято 3 http://194.44.11.130/cgi-bin/irbis_nbuv/cgiirbis_64.exe?C21COM=2\&I21DBN=ARD\&P21DBN=ARD\&IMAGE_ FILE_DOWNLOAD=1\&Z21ID=\&Image_file_name=DOC/2005/05ledtka.zip.

Lupo, G., \& Velicogna, M. (2018). Making EU Justice Smart? Looking into the Implementation of New Technologies to Improve the Efficiency of Cross Border Justice Services Delivery. In Rodríguez Bolívar, M. P. (Ed.), Smart Technologies for Smart Governments. Springer, New York, NY, pp. 95-121.

НАДС запускає чат-бот для пошуку державних вакансій. (2020). Узято з https://www.kmu.gov.ua/news/nads-zapustilo-chat-bot-dlya-poshuku-derzhavnih-vakansij.

Опендатабот: офіц. сайт. (2020). Узято з opendatabot.ua.

Положення про Міністерство цифрової трансформації України: затв. постановою Кабінету Міністрів України № 856. (2019). Узято з https://zakon.rada.gov.ua/laws/show/856-2019-\%D0\%BF\#n12.

Про доступ до публічної інформації: Закон України № 2939-VI. (2011). Узято з https://zakon.rada.gov.ua/laws/ show/2939-17\#Text.

Про інформацію: Закон України. № 2657-XII. (1992). Узято з https://zakon.rada.gov.ua/laws/show/2657-12.

Про схвалення Концепції розвитку цифрової економіки та суспільства України на 2018-2020 роки та затвердження плану заходів щодо іiі реалізації: розпорядження Кабінету Міністрів України № 67-р. (2018). Узято з https:// zakon.rada.gov.ua/laws/show/67-2018-p.

Про судову експертизу: Закон України № 4038-XII. (1994). Узято з https://zakon.rada.gov.ua/laws/show/4038-12.

Про затвердження Інструкції з організації проведення та оформлення експертних проваджень у підрозділах Експертної служби Міністерства внутрішніх справ України: наказ МВС України № 591. (2017). Узято 3 https:// zakon.rada.gov.ua/laws/show/z1024-17.

Присяжнюк, П. В. (2019). Демократична модель комунікації в системі державного управління України: сутність та основні елементи. Теорія та практика державного управління, 3 (66), 95-101.

DOI: https://doi.org/10.34213/tp.19.03.11.

Рувін, О. Г. (Заг. ред.). (2019). Судові експертизи в процесуальному праві Украӥни: навч. посіб. Київ: Ліра-К. 424 с.

Schneider, T., Meub, L., \& Bizer, K. (2016). Consumer Information in a Market for Expert Services: Experimental Evidence. SSRN Electronic Journal. DOI: $10.2139 /$ ssrn.2802129.

Seepma, A. P., de Blok, C., \& Van Donk, D. P. (2020). Designing digital public service supply chains: four country-based cases in criminal justice. Supply Chain Management.

DOI: https://doi.org/10.1108/SCM-03-2019-0111.

Щьокіна, Є. Ю., Царюк, Ю. С., \& Денісова, Є. В. (2019). Ефективні суспільні комунікації. Приазовський економічний вісник, 6 (17), 251-256. DOI: https://doi.org/10.32840/2522-4263/2019-6-46.

Шевченко, В. Е. (2019). Сервіси відкритих даних в Україні. Актуальні питання масової комунікацї, 26, 41-53. DOI: https://doi.org/10.17721/2312-5160.2019.26.41-53.

Скороход, В. (2017). Визначення засобів розробки чат-бота «помічник абітурієнта»для сучаснихмесенджерів. Узято 3 https://phm.cuspu.edu.ua/nauka/konferentsii/fizyka-tekhnolohii-navchannia/99-2017/komp-iuterni-nauky-ta-informatsiini-tekhnolohii/1118-vyznachennya-zasobiv-rozrobky-chat-bota-pomichnyk-abituriyenta-dlya-suchasnykh-mesendzheriv.html.

Цифрова адженда України - 2020: проєкт. (2016). 90 с. Узято з https://ucci.org.ua/uploads/files/58e78ee3c3922.pdf? cf_chl_jschl_tk_=325e284c5904a6785a25b589b8f01a4eea07fa05-1607426093-0-AfzFlAXphtT7Q6Hft_1-60y4cpWz_ CRCpDFxwNvIOOtt_nAQ_gLh6Tqif8WylkOucUKYag-tW7DoKdyOHRn0WW7H0jYoIiCmAzPZiylcJFtHcTaFPSPISIB8nCZbR2PIdDhV01wSyqyXfnkjwNGODO6G3TsOmvEg7tXYr1_NzyAy29JfX_KrjsWxSXanRGMNZKyvMaCG4mLf5YUIH6zMW30nAFz7Lk21M0ZoUR7rHHYsh3ofZjUqu_RyBTKH4JMi2TvpbcXPBQ9ThovgLN4LlvI51ZI77w4bC-F6y50JzGrMQ1CAKGn_32YjmAos52M9R2MvifUQuo-4eFP8GHjr0uWTd255FGxWzlDltxnNsqgo. 
Цифрова стратегія України 2020: успішна інтеграція України у глобальний ринок (2017, Берез. 6). Узято з httрs:// ckp.in.ua/events/16407.

Venkatesh, V., Thong, J. Y. L., Chan, F. K., \& Hu, P. J. H. (2016). Managing Citizens' Uncertainty in E-Government Services: The Mediating and Moderating Roles of Transparency and Trust. Information Systems Research, 27 (1), 87-111. DOI: https://doi.org/10.1287/isre.2015.0612.

Vial, G. (2019). Understanding digital transformation: A review and a research agenda. The Journal of Strategic Information Systems, 28 (2), 118-144.

DOI: https://doi.org/10.1016/j.jsis.2019.01.003.

В Україні працює електронний сервіс-чат-бот «Держслужбовеиь Тарас». (2018). Узято з https://khoda.gov.ua/vukra\%D1\%97n\%D1\%96-pracju\%D1\%94-.

Стаття надійшла до редакиї 23.04.2020

\author{
V. Kovalov, Ph.D in Law, \\ Deputy Head, \\ Donetsk Scientific Research Forensic Center, \\ MIA of Ukraine, \\ Mariupol, Donetsk region, Ukraine \\ ORCID: https://orcid.org/0000-0001-7172-5832
}

\title{
MODERN ELECTRONIC SERVICES AS A MEANS OF COMMUNICATION BETWEEN EXPERT INSTITUTIONS AND CUSTOMERS OF EXPERT SERVICES
}

\begin{abstract}
The purpose of the article is the formation of new theoretical provisions and development of the existing ones, as well as opportunities for the use of electronic services as a means of communication of expert institutions with customers and providing proposals and practical recommendations. Methodology. To investigate the organizational and technical provisions and principles of introducing modern means of communication the dialectical method was use as the principal one. It allowed to consider the subject of the article in the totality and the relationship of its components. In addition, the tasks set to achieve the goal were solved by using a set of general scientific and special methods, including formal and logical ones (analysis, synthesis, deduction, induction, analogy, abstraction), the system and structural one as well as legal comparison. The results of the investigation are based on the generalization of information on current trends in the development of communication in state institutions, in particular in the units of the Expert Service of the Ministry of Internal Affairs. Scientific novelty. The necessity of creating a system of interaction of expert institutions with customers of expert services on the platform of chat bots has been substantiated, the sequence of such interaction has been offered. Conclusions. The need to optimize the communication between the subjects of forensic activity is justified by the organizational and legal features of forensic examinations. The experience of using chat bots by state institutions and public organizations has been generalized. It testifies to the convenience of services that correspond to the best practices. The advantages of this means of communication have been outlined, which makes it a full-fledged intangible asset. The risks are that chat bots need to be used properly and they do not solve complex problems. The system of interaction of expert institutions with service customers has been developed and the sequence of such interaction has been proposed. The service menu (bot) provides options: «My documents», «My messages». Suggestions and recommendations for the usage of chat bots in expert institutions as a means of communication have been provided.
\end{abstract}

Keywords: state institution; forensic expertise; forensic activity; customer of expert services; digitalization; electronic services; chat bot. 
В. В. Ковалев, кандидат юридических наук,

заместитель директора,

Донеикий научно-исследовательский экспертно-

криминалистический центр МВД Украинь,

2. Мариуполь, Донеикая обл.

ORCID: https://orcid.org/0000-0001-7172-5832

\title{
СОВРЕМЕННЫЕ ЭЛЕКТРОННЫЕ СЕРВИСЫ КАК СРЕДСТВО КОММУНИКАЦИИ ЭКСПЕРТНЫХ УЧРЕЖДЕНИЙ С ЗАКАЗЧИКАМИ ЭКСПЕРТНЫХ УСЛУГ
}

\begin{abstract}
Цель статьи - формирование новых и развитие действующих теоретических положений, а также практических возможностей использования электронных сервисов как средства коммуникации экспертных учреждений с заказчиками, предоставление предложений и практических рекомендаций. Методология. Для исследования организационно-технических основ, положений и принципов внедрения современных средств коммуникации как основной использован диалектический метод, что позволило рассмотреть предмет статьи в совокупности и взаимосвязи его составляющих. Кроме того, поставленные для достижения цели задачи решались с помощью комплекса общенаучных и специальных методов, в том числе формально-логических (анализ, синтез, дедукция, индукция, аналогия, абстрагирование), системно-структурного и сравнительно-правового. Результаты исследования основываются на обобщении сведений о современных тенденциях развития коммуникации в государственных учреждениях, в частности в подразделениях Экспертной службы МВД. Научная новизна. Обоснована необходимость создания системы взаимодействия экспертных учреждений с заказчиками экспертных услуг на платформе чат-ботов, предложен порядок такого взаимодей-

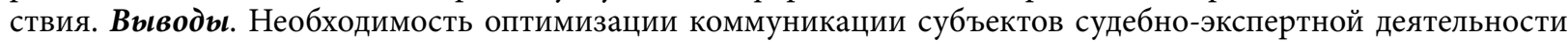
аргументирована организационно-правовыми особенностями выполнения судебных экспертиз. Обобщен опыт использования государственными учреждениями и общественными организациями чат-ботов, подтверждающих удобство сервисов, которые соответствуют наилучшим практикам. Определены преимущества указанного средства коммуникации, делающие его полноценным нематериальным активом, и риски, вызванные тем, что требующие правильного использования чат-боты не решают сложных вопросов. Разработана система взаимодействия экспертных учреждений с заказчиками услуг и предложен порядок такого взаимодействия. В меню сервиса (бота) предусмотрены опции «Мои документы», «Мои сообщения». Сделаны предложения и даны рекомендации по использованию в экспертных учреждениях чат-ботов как средства коммуникации.
\end{abstract}

Ключевые слова: государственное учреждение; судебная экспертиза; судебно-экспертная деятельность; заказчик экспертных услуг; цифровизация; диджитализация; электронные сервисы; чат-бот. 